\title{
Siirt ekolojik şartlarında ikinci ürün olarak yetiştirilen bazı susam (sesamum mdicum, l.) genotiplerinin yağ asidi kompozisyonlarının belirlenmesi
}

\author{
Determination of fatty acid compositions of some sesame (sesamum indicum, l.) genotype \\ grown as second crop in Siirt ecological conditions
}

\author{
Yasin YAKAR*1,a, Hüseyin ARSLAN ${ }^{2, b}$, Aynur BÍLMEZ ÖZÇINAR ${ }^{2, c}$ \\ ${ }^{1}$ Harran Üniversitesi, Mühendislik Fakültesi, Gıda Mühendisliği Bölümü, 63100, Şanlıurfa \\ ${ }^{2}$ Siirt Üniversitesi, Ziraat Fakültesi, Tarla Bitkileri Bölümü, 56100, Siirt
}

• Geliş tarihi / Received: 04.05.2020 • Düzeltilerek geliş tarihi / Received in revised form: 27.10.2020 • Kabul tarihi / Accepted: 10.11 .2020

\begin{abstract}
Öz
$\mathrm{Bu}$ araştırma, Siirt Üniversitesi Ziraat Fakültesi deneme alanında ikinci ürün koşullarında yetiştirilen 10 adet susam (Sesamum indicum L.) genotiplerinin (3 adet tescilli, 7 adet hat) yağ asidi kompozisyonlarının belirlenmesi amaciyla yapılmıştır. Soxhelet yöntemiyle susam tohumlarından elde edilen yağların, metillendirme işleminden sonra Gaz Kromatografisi cihazı kullanılarak, yağ asitleri bileşimi analiz edilmiştir. İstatistiksel değerlendirme sonucunda, susam yağında oleik asit (C18:1), linoleik asit (C18:2) ve stearik asit (C18:0) oranlarının hem çeşit hem yıl bakımından; palmitik asit $(\mathrm{C} 16: 0)$ oranının ise sadece yıl bakımından istatistiksel olarak önemli düzeyde $(\mathrm{P}<0.05)$ farklılık gösterdiği tespit edilmiştir. Susam tohumu yağlarında oleik asit (\%45.82), linoleik asit (\%37.50), palmitik asit (\%9.11) ve stearik asitlerin (\%5.99) en fazla bulunan yağ asitleri olduğu belirlenmiştir.
\end{abstract}

Anahtar kelimeler: Sesamum Indicum L., Susam, Susam yağı, Yağ asitleri kompozisyonu

\begin{abstract}
This research was carried out to determine the fatty acid composition of 10 sesame (Sesamum indicum L.) genotypes (3 of them registered and 7 of them lines) grown under second crop conditions in experimental area of Agriculture Faculty of Siirt University. Sesame oils of the genotypes obtained by Soxhlet method were methylated and than analyzed for fatty acid composition by means of Gas Chromatography device. As a result of the statistical evaluation, the oleic acid (C18:1), linoleic acid (C18:2) and stearic acid (C18: O) ratios in sesame oil both in terms of variety and year; palmitic acid $(C 16: 0)$ ratio was found to be statistically significant $(P<0.05)$ only in terms of years. The major fatty acids are oleic acid (45.82\%), linoleic acid (37.50\%), palmitic acid (9.11\%) and stearic acids (5.99\%) in sesame seed oils.
\end{abstract}

Keywords: Sesamum Indicum L., Sesame, Sesame oil, Fatty acids composition

\footnotetext{
*a Yasin YAKAR; yasinyakar@harran.edu.tr, Tel: (0505) 34392 10, orcid.org/0000-0003- 3297- 3379

${ }^{\mathrm{b}}$ orcid.org/0000-0001-7221-7952 $\quad{ }^{\mathrm{c}}$ orcid.org/0000-0002-3173-6147
} 


\section{Giriş}

Pedaliaceae familyasının bir üyesi olan Susam bitkisi (Sesamum indicum L.), başlica tropikal ve subtropikal bölgeler olmak üzere, dünyanın birçok yerinde yetiştirilen ekonomik açıdan önemli yağlı tohumlu bitkilerden birisidir (Hama, 2017; Özdemir vd., 2018; Ayoubizadeh vd., 2019). Susam dünyada ağırlıklı olarak Asya, Akdeniz ve Güney Afrika'da üretilmektedir. Çin, Hindistan, Myanmar, Sudan, Etiyopya, Nijerya, Meksika ve Guatemala, susam için önemli üretim alanlarıdır (Ji, 2018). Susam başta tahin, helva ve unlu mamuller olmak üzere margarin, boya, kozmetik, parfüm ve sabun üretiminde de kullanılmaktadır (Nzikou vd., 2009; Şaman ve Öztürk 2012; Kurt vd., 2016).

Susam tohumları \%35-63 yağ, \%18-25 protein ve \%11-13.5 karbohidrat içerir. Yağında bulunan sesamol, sesaminol ve tokoferoller gibi antioksidanlar sayesinde oksidatif bozulmaya karşı oldukça dirençlidir (Were vd., 2006; Spandana vd., 2013; Chen vd., 2014; Hama, 2017) ve diğer bitkisel yağlara kıyasla daha uzun bir raf ömrüne sahiptir.

Susam yağında bulunan oleik asit ve linoleik asit majör yă asitleri olup toplam yağ asitlerinin $\% 80$ 'den fazlasını oluştururlar. Yüksek miktardaki tekli doymamış yağ asitleri (TDYA) ve çoklu doymamış yağ asitleri (ÇDYA) insan tüketimi için yağın kalitesini arttırır. Ayrıca, kan kolesterolünü ve hipertansiyonu düşürmede, kardiyovasküler hastalık riskini azaltmada, aterosklerozu önlemede önemli rol oynar. Gözlenen etkiler, düşük seviyede doymuş yağ asitleri ve antioksidanların varlığı ile karakterize edilen yağın kimyasal bileşimine bağlanmıştır (Were vd., 2006; Uzun vd., 2008; Elleuch vd., 2007; Mondal vd., 2010; Arslan vd., 2014; Kurt vd., 2016; Hashempour vd., 2017).

Ülkemizde susam; başta Ege Bölgesi olmak üzere sırasıyla, Akdeniz, Batı Marmara ve Güneydoğu Anadolu bölgelerinde yetiştirilmektedir. Ana ürün olarak tarımı yapılabildiği gibi yetişme süresinin kısalığından dolayı ikinci ürün olarak da tarımı yapılabilmekte ve çoğu kültür bitkisi ile ekim nöbetine girebilmektedir (Seçer, 2016).

$\mathrm{Bu}$ çalışmayla, Siirt ili ekolojik koşullarında ikinci ürün olarak yetiştirilen 3'ü tescilli, 7'si hat olmak üzere toplam 10 farklı susam genotipinden elde edilen yağların yă̆ asidi kompozisyonlarının belirlenmesi amaçlanmıştır.

\section{Materyal ve metot}

\subsection{Materyal}

$\mathrm{Bu}$ araştırma, Siirt Üniversitesi Kezer yerleşkesi Ziraat Fakültesi deneme alanında 2016-2017 yıllarında ikinci ürün koşullarında yetiştirilen bazı susam (Sesamum indicum L.) genotiplerinin yă asidi kompozisyonlarının belirlenmesi amaciyla yapılmıştır. Kezer yerleşkesi Ziraat Fakültesi deneme alanı Siirt'e $10 \mathrm{~km}$ uzaklıkta olup, denizden yüksekliği 585 m'dir. Denemenin yürütüldüğü yıllar ve uzun yıllar ortalamasına ilişkin iklim değerleri Tablo 1'de verilmiştir.

Denemede kullanılan susam çeşit ve hatları, Şanlıurfa GAP Tarımsal Araştırma Enstitüsünden temin edilmiştir. Deneme, her iki yılda da ön ürün olarak ekilen arpanın hasadından sonra sırasıyla 18 ve 20 Haziran tarihlerinde tesadüf blokları deneme desenine göre üç tekerrürlü olarak gerçekleştirilmiştir. Denemede parsel boyu 6 metre, her parselde dört sıra, sira aras $70 \mathrm{~cm}$ ve sira üzeri ise $15 \mathrm{~cm}$ olarak uygulama yapılmıştır. Yetişme sezonu boyunca hiç yağış olmamış ve çıkış suyu ile birlikte toplam 6 kez damla sulama yöntemiyle sulama yapılmıştır. Denemede ekimle birlikte dekara saf olarak $8 \mathrm{~kg}$ fosfor ve $4 \mathrm{~kg}$ azot gelecek şekilde Triple Süper Fosfat ve Üre gübresi uygulanmıştır. Hasatlar her iki yılda da ekim ayında (sırasıyla 10 ve 12 Ekim) yapılmıştır.

\subsection{Metot}

Yağ asitleri kompozisyonunu belirlemek amaciyla tüm susam genotiplerinden soxhlet yöntemiyle yağlar ekstrakte edilmiştir. Ekstrakte edilen yağlar metilleştirme işlemine kadar derin dondurucuda $18{ }^{\circ} \mathrm{C}$ 'de muhafaza edilmiştir.

Analizlerde kullanılan izooktan $\left(\mathrm{C}_{8} \mathrm{H}_{18}, \% 99.5\right)$, sodyum hidrojen sülfat $\left(\mathrm{NaHSO}_{4}, \% 99\right)$, sodyum klorür $(\mathrm{NaCl}, \% 99.5)$ ve $2 \mathrm{~N}$ metanollü potasyum hidroksit (KOH) Merck'ten (Darmstadt, Almanya) temin edilmiştir.

Yağ asitlerinin gaz kromatografisinde analiz edilebilmesi için metilleştirmesi gerekmektedir. $\mathrm{Bu}$ işlem TS EN ISO 12966:2 metoduna göre gerçekleştirilmiştir. Deney tüpüne $100 \mathrm{mg}$ yağ numunesi ve $2 \mathrm{ml}$ izooktan çözeltisi konulduktan sonra karıştırılmıştır. $200 \quad \mu 1 \quad 2 \quad \mathrm{~N}$ metanollü potasyum hidroksit $(\mathrm{KOH})$ çözeltisi ilave edilerek $1 \mathrm{dk}$ süreyle tekrar karıştırılmıştır. Daha sonra tüpün içerisine \% 40 'llk NaCl çözeltisinden $2 \mathrm{ml}$ ilave edilerek çalkalanmıştır. Üstteki izooktan fazı bir viale aktarılmış ve yaklaşık $1 \mathrm{~g}$ kadar sodyum 
hidrojen sülfat ilave edilerek karıştırılmıştır. $30 \mathrm{dk}$ kadar dinlendirildikten sonra üst kısımdaki fazdan $1 \mu 1$ alınarak gaz kromatografi cihazına enjekte edilmiştir (TS EN ISO 12966-2, 2017).

Yağ asitleri bileşiminin belirlenebilmesi amacıyla, Thermo marka, TraceGC Ultra model, FID (Flame Ion Dedector) dedektörlü gaz kromatografisi cihazı kullanılmıştır. Yağ asitlerinin ayırımı için 30 m'lik ZB-WAX kolon kullanılmışıtır. 37'li yağ asitleri standartı Sigma-Aldrich (St Louis, MO, USA) firmasından temin edilmiştir. Dedektör ve injektör bloğu sıcaklıkları sirasıly 280 ve $250{ }^{\circ} \mathrm{C}$ olarak ayarlanmıştır. Kolona sicaklık programı uygulanmıştır. $50{ }^{\circ} \mathrm{C}$ 'de $2 \mathrm{dk}$ beklendikten sonra $20{ }^{\circ} \mathrm{C} / \mathrm{dk}$ artışla $180{ }^{\circ} \mathrm{C}$ 'ye, bu sıcaklıktan ise $5^{\circ} \mathrm{C} / \mathrm{dk}$ artışla $230{ }^{\circ} \mathrm{C}$ 'ye çıkılmış ve bu sıcaklıkta $5.5 \mathrm{dk}$ beklenmiştir. Split oranı 1/50 ve injeksiyon miktarı $1 \mu$ olarak ayarlanmıştır

Her bir numune üç tekerrürlü olarak analiz edilmiştir. Elde edilen veriler, tesadüf blokları deneme desenine göre JMP (John's Macintosh Project) istatistik paket programı kullanılarak varyans analizine tabi tutulmuştur. Varyans analizi sonucu önemli bulunan ortalamalar LSD (Least Significant Difference)'ye göre gruplandırılmıştır.

Tablo 1. Denemenin yürütüldüğü yıllar ve uzun yıllar ortalamasına ilişkin iklim değerleri

\begin{tabular}{|c|c|c|c|c|c|}
\hline Aylar & Yillar & $\begin{array}{l}\text { Aylık Ort.Maks. } \\
\text { Sicaklık }\left({ }^{\circ} \mathrm{C}\right)\end{array}$ & $\begin{array}{l}\text { Aylik Ort.Min. } \\
\text { Sicaklık }\left({ }^{\circ} \mathrm{C}\right)\end{array}$ & $\begin{array}{c}\text { Aylik Ort. } \\
\text { Sicaklık }\left({ }^{\circ} \mathrm{C}\right)\end{array}$ & $\begin{array}{c}\text { Aylık Ort.Nispi } \\
\text { Nem }(\%)\end{array}$ \\
\hline \multirow{3}{*}{ Mayıs } & 2016 & 25.3 & 14.3 & 19.9 & 48.9 \\
\hline & 2017 & 25.1 & 13.9 & 19.5 & 51.7 \\
\hline & Uzun Yillar Ort. & 25.2 & 13.5 & 19.3 & 41.5 \\
\hline \multirow{3}{*}{ Haziran } & 2016 & 32.4 & 20.3 & 26.5 & 32.7 \\
\hline & 2017 & 33.2 & 20.0 & 26.9 & 29.5 \\
\hline & Uzun Yillar Ort. & 32.1 & 18.9 & 26.0 & 24.1 \\
\hline \multirow{3}{*}{ Temmuz } & 2016 & 36.3 & 24.3 & 31.4 & 24.5 \\
\hline & 2017 & 39.1 & 24.8 & 32.3 & 19.0 \\
\hline & Uzun Yillar Ort. & 36.9 & 23.4 & 30.6 & 18.1 \\
\hline \multirow{3}{*}{ Ağustos } & 2016 & 36.8 & 25.1 & 32.3 & 20.5 \\
\hline & 2017 & 39.3 & 24.5 & 32.0 & 19.0 \\
\hline & Uzun Yillar Ort. & 36.8 & 23.1 & 30.1 & 17.2 \\
\hline \multirow{3}{*}{ Eylül } & 2016 & 31.5 & 18.7 & 25.0 & 29.8 \\
\hline & 2017 & 35.8 & 21.5 & 28.4 & 19.1 \\
\hline & Uzun Yillar Ort. & 32.2 & 18.7 & 25.1 & 24.0 \\
\hline \multirow{3}{*}{ Ekim } & 2016 & 26.3 & 13.8 & 19.5 & 36.8 \\
\hline & 2017 & 24.8 & 12.6 & 18.4 & 34.6 \\
\hline & Uzun Yillar Ort. & 24.3 & 12.6 & 17.9 & 45.3 \\
\hline
\end{tabular}

\section{Bulgular ve tartışma}

Dünya ortalamalarına baktığımızda susam yağlarının palmitik asit (C16:0) içeriği \% 8.3-10.9, stearik asit (C18:0) içeriği \% 3.4-6.0, oleik asit (C18:1) içeriği \% 32.7-53.9 ve linoleik asit (C18:2) içeriği \% 39.3-59.0 arasında değişim gösterdiği bildirilmiştir (Baydar, 2005). Türkiye'de yetiştirilen yerel susam çeşit ve popülasyonlarında ise \% 8.7-10.2 arasında palmitik asit (C16:0), \% 4.0-5.0 arasinda stearik (C18:0), \% 41.1-47.2 arasinda oleik asit (C18:1) ve \% 38.2-43.4 arasinda linoleik asit (C18:2) bulunduğu tespit edilmiştir (Baydar vd., 1999).

2016 yılına ait susam genotiplerinde yağ asitleri kompozisyonu Tablo 2'de verilmiştir. Tablo incelendiğinde oleik asit (C18:1) ve linoleik asidin (C18:2) majör doymamış yağ asitleri olduğu, bunları sırasıyla doymuş yağ asitleri olan palmitik asit (C16:0) ve stearik asidin (C18:0) izlediği görülmektedir. Susam yağlarında oleik asit (C18:1) yüzdesi, ortalama $\% 46.16$ değerle $\% 45.46$ ile 47.43 arasında değişmektedir. Linoleik asit (C18:2) \%35.32 ile 37.75 arasında değişirken, ortalama değer \%36,91'dir.

Aynı çeşitlerin bir sonraki yıla ait değerleri incelendiğinde oleik asidin (C18:1) yine baskın yă asidi olduğu görülmektedir. Oleik asit (C18:1) ve linoleik asite (C18:2) ait değerler sirasıyla \% 45.46 46.82 ve \%36.33-39.54 arasında değişmektedir. Ortalama değerler ise sirasiyla $\% 45.47$ ve $\% 38.10$ olarak bulunmuştur (Tablo 3).

Her iki yılda da palmitik asit (C16:0) ve stearik asidin (C18:0) önemli doymuş yağ asitleri olduğu görülmektedir. Palmitik asit (C16:0) değerleri 2016 y1lında \%8.76-9.71, 2017 y1lında ise \%8.54-9.13 değişirken ortalama değer $\% 9.11$ olarak tespit 
edilmiştir. Stearik asite (C18:0) ait değerler ise sirasiyla \%5.44-6.33 ve \%5.79-6.57 arasinda tespit edilmiş olup ortalama değer \%5.99'dur (Tablo 24).

Yağ bitkilerinin yağ asitleri kompozisyonu sürekli sabit değildir ve çeşitli fizyolojik, ekolojik ve kültürel faktörlerin etkisi altında az çok değişebilmektedir. Birçok yağ bitkisinde yăg asitlerinin bașta sıcaklık olmak üzere çeșitli iklim koşullarına duyarlı olduğu saptanmıştır (Baydar ve Turgut, 1999). Genel olarak baktığımızda; oleik (C18:1), linoleik (C18:2) ve stearik asitte (C18:0) hem çeşit hem de y1l bazında, palmitik asitte (C16:0) ise sadece y1l bazında istatistiki olarak önemli farkl11ıklar görülmektedir (Tablo 5). Bu farklılığın 2016-2017 yılları arasındaki sıcaklık farkından kaynaklandığı düşünülmektedir (Tablo $1)$.

Mondal vd., (2010) 33 farklı susam tohumunda yaptıkları bir çalışmada oleik asidi (C18:1) majör yağ asidi olarak tespit etmiş olup $(\% 45.9)$ bu durum çalışmamızla benzerlik göstermektedir. Diğer bir majör yă̆ asidi olan linoleik asidi (C18:2) ise \%40.5 olarak tespit etmişlerdir. Sudan'da yapılan bir çalışmada oleik asit (C18:1) \%44.06, linoleik asit (C18:2) \%35.56, palmitik asit (C16:0) \%11.18 ve stearik asit (C18:0) \%6.40 olarak tespit edilmiştir (Elleuch vd., 2007). Bu sonuçlar kendi çalışmamızla benzerlik göstermektedir.

Tablo 2. 2016 yılına ait yağ asitleri kompozisyonu

\begin{tabular}{cccccccccc}
\hline Susam çeşitleri & C16:0 & C16:1 & C18:0 & C18:1 & C18:2 & C18:3 & C20:0 & C20:1 & C22:0 \\
\hline Arslanbey & 9.26 & $0.18 \mathrm{a}$ & $5.77 \mathrm{~cd}$ & $45.61 \mathrm{bc}$ & $37.75 \mathrm{a}$ & $0.31 \mathrm{e}$ & 0.58 & 0.21 & 0.11 \\
Hatipoğlu & 9.57 & $0.18 \mathrm{a}$ & $5.62 \mathrm{de}$ & $46.05 \mathrm{bc}$ & $37.24 \mathrm{a}-\mathrm{c}$ & $0.35 \mathrm{~cd}$ & 0.54 & 0.19 & 0.09 \\
Boydak & 9.56 & $0.10 \mathrm{~cd}$ & $6.00 \mathrm{bc}$ & $45.71 \mathrm{bc}$ & $37.18 \mathrm{a}-\mathrm{c}$ & $0.36 \mathrm{bc}$ & 0.57 & 0.19 & 0.10 \\
Sus-4 & 9.71 & $0.14 \mathrm{bc}$ & $5.91 \mathrm{~b}-\mathrm{d}$ & $45.56 \mathrm{bc}$ & $37.15 \mathrm{a}-\mathrm{c}$ & $0.35 \mathrm{bc}$ & 0.61 & 0.21 & 0.11 \\
Sus-6 & 9.36 & $0.11 \mathrm{~b}-\mathrm{d}$ & $5.99 \mathrm{bc}$ & $46.27 \mathrm{~b}$ & $36.76 \mathrm{c}$ & $0.37 \mathrm{bc}$ & 0.61 & 0.21 & 0.12 \\
Sus-7 & 8.76 & $0.10 \mathrm{~cd}$ & $6.16 \mathrm{ab}$ & $47.43 \mathrm{a}$ & $35.92 \mathrm{~d}$ & $0.32 \mathrm{de}$ & 0.62 & 0.22 & 0.12 \\
Sus-8 & 9.35 & $0.09 \mathrm{~d}$ & $6.33 \mathrm{a}$ & $47.29 \mathrm{a}$ & $35.32 \mathrm{~d}$ & $0.37 \mathrm{bc}$ & 0.67 & 0.22 & 0.13 \\
Sus-10 & 9.27 & $0.11 \mathrm{~b}-\mathrm{d}$ & $5.98 \mathrm{bc}$ & $46.16 \mathrm{bc}$ & $36.98 \mathrm{bc}$ & $0.32 \mathrm{de}$ & 0.65 & 0.22 & 0.13 \\
Sus-26 & 9.42 & $0.14 \mathrm{~b}$ & $5.74 \mathrm{c}-\mathrm{e}$ & $46.06 \mathrm{bc}$ & $37.12 \mathrm{a}-\mathrm{c}$ & $0.38 \mathrm{~b}$ & 0.64 & 0.22 & 0.13 \\
Sus-27 & 9.71 & $0.13 \mathrm{~b}-\mathrm{d}$ & $5.44 \mathrm{e}$ & $45.46 \mathrm{c}$ & $37.66 \mathrm{ab}$ & $0.43 \mathrm{a}$ & 0.63 & 0.22 & 0.14 \\
Ortalama & 9.40 & 0.13 & 5.89 & 46.16 & 36.91 & 0.36 & 0.61 & 0.21 & 0.12 \\
LSD & --- & 0.04 & 0.33 & 0.76 & 0.77 & 0.03 & --- & --- & --- \\
RSD $(\%)$ & 3.91 & 16.23 & 3.21 & 9.61 & 1.22 & 5.26 & 9.31 & 12.15 & 18.33 \\
\hline
\end{tabular}

Aynı sütunda farklı harflerle gösterilen ortalamalar farklıdır $(\mathrm{p}<0.05)$

Tablo 3. 2017 y1lına ait yağ asitleri kompozisyonu

\begin{tabular}{cccccccccc}
\hline Susam çeşitleri & C16:0 & C16:1 & C18:0 & C18:1 & C18:2 & C18:3 & C20:0 & C20:1 & C22:0 \\
\hline Arslanbey & $9.07 \mathrm{a}$ & 0.11 & $5.79 \mathrm{~d}$ & $44.15 \mathrm{c}$ & $39.54 \mathrm{a}$ & 0.29 & $0.59 \mathrm{~cd}$ & 0.21 & $0.12 \mathrm{~cd}$ \\
Hatipoğlu & $8.54 \mathrm{c}$ & 0.10 & $5.88 \mathrm{~cd}$ & $45.61 \mathrm{ab}$ & $38.47 \mathrm{a}-\mathrm{c}$ & 0.33 & $0.58 \mathrm{~d}$ & 0.22 & $0.12 \mathrm{~b}-\mathrm{d}$ \\
Boydak & $8.90 \mathrm{ab}$ & 0.10 & $6.24 \mathrm{a}-\mathrm{c}$ & $44.15 \mathrm{c}$ & $39.21 \mathrm{ab}$ & 0.29 & $0.62 \mathrm{~b}-\mathrm{d}$ & 0.21 & $0.11 \mathrm{~d}$ \\
Sus-4 & $8.89 \mathrm{a}-\mathrm{c}$ & 0.09 & 6.21 & $45.37 \mathrm{bc}$ & $38.00 \mathrm{a}-\mathrm{d}$ & 0.31 & $0.66 \mathrm{ab}$ & 0.21 & $0.14 \mathrm{a}$ \\
Sus-6 & $8.86 \mathrm{a}-\mathrm{c}$ & 0.11 & $6.30 \mathrm{ab}$ & $45.94 \mathrm{ab}$ & $37.35 \mathrm{~cd}$ & 0.32 & $0.65 \mathrm{ab}$ & 0.22 & 0.12 \\
Sus-7 & $8.60 \mathrm{~b}-\mathrm{c}$ & 0.08 & $6.15 \mathrm{~b}-\mathrm{c}$ & $45.83 \mathrm{ab}$ & $37.87 \mathrm{a}-\mathrm{d}$ & 0.33 & $0.64 \mathrm{ab}$ & 0.22 & $0.13 \mathrm{a}-\mathrm{d}$ \\
Sus-8 & $8.70 \mathrm{~b}-\mathrm{c}$ & 0.09 & $6.57 \mathrm{a}$ & $46.82 \mathrm{a}$ & $36.33 \mathrm{~d}$ & 0.34 & $0.68 \mathrm{a}$ & 0.22 & $0.13 \mathrm{a}-\mathrm{c}$ \\
Sus-10 & $8.66 \mathrm{~b}-\mathrm{c}$ & 0.09 & $6.05 \mathrm{~b}-\mathrm{c}$ & $45.55 \mathrm{ab}$ & $38.42 \mathrm{a}-\mathrm{c}$ & 0.30 & $0.64 \mathrm{ab}$ & 0.21 & $0.13 \mathrm{ab}$ \\
Sus-26 & $8.93 \mathrm{ab}$ & 0.10 & $5.89 \mathrm{~cd}$ & $45.65 \mathrm{ab}$ & $37.99 \mathrm{a}-\mathrm{d}$ & 0.33 & $0.64 \mathrm{a}-\mathrm{c}$ & 0.22 & $0.14 \mathrm{a}$ \\
Sus-27 & $9.13 \mathrm{a}$ & 0.10 & $5.85 \mathrm{~cd}$ & $45.64 \mathrm{ab}$ & $37.83 \mathrm{~b}-\mathrm{d}$ & 0.34 & $0.64 \mathrm{a}-\mathrm{c}$ & 0.22 & $0.14 \mathrm{a}$ \\
Ortalama & 8.83 & 0.10 & 6.09 & 45.47 & 38.10 & 0.32 & 0.63 & 0.22 & 0.13 \\
LSD & 0.36 & --- & 0.41 & 1.40 & 1.68 & --- & 0.04 & --- & 0.013 \\
RSD $(\%)$ & 2.36 & 10.06 & 3.92 & 1.80 & 2.57 & 8.88 & 4.00 & 3.20 & 6.16 \\
\hline Ay
\end{tabular}

Aynı sütunda farklı harflerle gösterilen ortalamalar farklıdır $(\mathrm{p}<0.05)$ 
Baydar vd., (1999) 72 farklı Türk susam çeşidinde oleik asit (C18:1) miktarını \%41.1-47.2, linoleik asit (C18:2) miktarını \%38.2-43.4, palmitik asit (C16:0) miktarın \%8.7-10.2 ve stearik asit (C18:0) miktarını ise \%4-5 arasında bulmuşlardır. Kuzey bölgelerde yetişen susamların daha fazla linoleik asit (C18:2) ve palmitik asit (C16:0), daha az stearik asit (C18:0) ve oleik asit (C18:1) içerdiklerini tespit etmişlerdir.

Dar vd., (2019), Hindistan'ın farklı tarımsal iklim bölgelerinden 43 farklı susam çeşidinde 3 yıl süren bir deneme gerçekleştirmişlerdir. Susam yağında linoleik asit (C18:2) miktarını ortalama \%43.24, oleik asit (C18:1) miktarını ise \%41.06 olarak bulmuşlardır.
Ünal ve Yalçın (2008), Antalya ve Menemen'den elde ettikleri 4 farklı susam çeşidinde yağ asitleri kompozisyonlarını belirlemişlerdir. Linoleik asit (C18:2), oleik asit (C18:1), palmitik asit (C16:0) ve stearik asite (C18:0) ait ortalama değerleri sırasiyla $\% 42.74, \% 41.55, \% 8.90$ ve $\% 5.43$ olarak tespit etmişlerdir. Yapmış olduğumuz çalışmada oleik asit (C18:1) majör yă̆ asidi iken bu çalışmada linoleik asit (C18:2) majör yăg asidi olarak görülmektedir. Were et al., (2006) ve Karaaslan, (2007) çalışmalarında mevcut çalışmamızdan faklı olarak linoleik asidi (C18:2) majör yağ asidi olarak tespit etmişlerdir.

Tablo 4. 2016-2017 y1llarına ait ortalama yağ asitleri kompozisyonu

\begin{tabular}{cccccccccc}
\hline Susam çeşitleri & C16:0 & C16:1 & C18:0 & C18:1 & C18:2 & C18:3 & C20:0 & C20:1 & C22:0 \\
\hline Arslanbey & $9.17 \mathrm{ab}$ & $0.14 \mathrm{a}$ & $5.78 \mathrm{de}$ & $44.88 \mathrm{~d}$ & $38.65 \mathrm{a}$ & $0.297 \mathrm{f}$ & $0.59 \mathrm{bc}$ & 0.21 & $0.12 \mathrm{~b}-\mathrm{d}$ \\
Hatipoğlu & $9.06 \mathrm{~b}$ & $0.14 \mathrm{a}$ & $5.75 \mathrm{e}$ & $45.83 \mathrm{c}$ & $37.85 \mathrm{a}-\mathrm{c}$ & $0.336 \mathrm{~b}-\mathrm{e}$ & $0.56 \mathrm{c}$ & 0.21 & $0.11 \mathrm{~d}$ \\
Boydak & $9.23 \mathrm{ab}$ & 0.103 & $6.12 \mathrm{~b}$ & $44.93 \mathrm{~d}$ & $38.19 \mathrm{ab}$ & $0.326 \mathrm{c}-\mathrm{e}$ & $0.60 \mathrm{bc}$ & 0.20 & $0.11 \mathrm{~cd}$ \\
Sus-4 & $9.30 \mathrm{ab}$ & $0.12 \mathrm{bc}$ & $6.06 \mathrm{bc}$ & $45.47 \mathrm{~cd}$ & $37.58 \mathrm{~b}-\mathrm{d}$ & $0.331 \mathrm{~b}-\mathrm{e}$ & $0.63 \mathrm{ab}$ & 0.21 & $0.13 \mathrm{a}-\mathrm{c}$ \\
Sus-6 & $9.11 \mathrm{ab}$ & 0.11 & $6.15 \mathrm{~b}$ & $46.11 \mathrm{bc}$ & $37.05 \mathrm{~cd}$ & $0.343 \mathrm{~b}-\mathrm{d}$ & $0.63 \mathrm{ab}$ & 0.21 & $0.12 \mathrm{a}-\mathrm{d}$ \\
Sus-7 & $8.68 \mathrm{c}$ & 0.09 & $6.16 \mathrm{~b}$ & $46.63 \mathrm{ab}$ & $36.89 \mathrm{~d}$ & $0.323 \mathrm{~d}-\mathrm{f}$ & $0.63 \mathrm{ab}$ & 0.22 & $0.12 \mathrm{a}-\mathrm{d}$ \\
Sus-8 & $9.02 \mathrm{bc}$ & 0.09 & $6.45 \mathrm{a}$ & $47.06 \mathrm{a}$ & $35.83 \mathrm{e}$ & $0.351 \mathrm{bc}$ & $0.67 \mathrm{a}$ & 0.22 & $0.13 \mathrm{ab}$ \\
Sus-10 & $8.97 \mathrm{bc}$ & 0.09 & $6.02 \mathrm{~b}-\mathrm{d}$ & $45.85 \mathrm{c}$ & $37.70 \mathrm{~b}-\mathrm{d}$ & $0.312 \mathrm{ef}$ & $0.65 \mathrm{a}$ & 0.22 & $0.13 \mathrm{a}$ \\
Sus-26 & $9.18 \mathrm{ab}$ & $0.12 \mathrm{~b}$ & $5.81 \mathrm{c}-\mathrm{e}$ & $45.86 \mathrm{c}$ & $37.56 \mathrm{~b}-\mathrm{d}$ & $0.356 \mathrm{ab}$ & $0.64 \mathrm{ab}$ & 0.22 & $0.14 \mathrm{a}$ \\
Sus-27 & $9.42 \mathrm{a}$ & 0.112 & $5.65 \mathrm{e}$ & $45.55 \mathrm{~cd}$ & $37.75 \mathrm{~b}-\mathrm{d}$ & $0.383 \mathrm{a}$ & $0.63 \mathrm{ab}$ & 0.22 & $0.14 \mathrm{a}$ \\
Ortalama & 9.11 & 0.11 & 5.99 & 45.82 & 37.50 & 0.34 & 0.62 & 0.21 & 0.12 \\
LSD & 0.35 & 0.02 & 0.25 & 0.76 & 0.89 & 0.03 & 0.05 & --- & 0.02 \\
RSD $(\%)$ & 3.28 & 14.39 & 3.60 & 1.43 & 2.03 & 7.11 & 7.09 & 8.80 & 13.23 \\
\hline Ay
\end{tabular}

Aynı sütunda farklı harflerle gösterilen ortalamalar farklıdır $(\mathrm{p}<0.05)$

Tablo 5. Susam çeşitlerine ait yağ asitleri kompozisyonlarının varyans analizi

\begin{tabular}{cccccccccc}
\hline & C16:0 & C16:1 & C18:0 & C18:1 & C18:2 & C18:3 & C20:0 & C20:1 & C22:0 \\
\hline Çeşit & ÖD & $* *$ & $* * *$ & $* * *$ & $* *$ & $* * *$ & $* *$ & ÖD & $*$ \\
Yıl & $* * *$ & $* * *$ & $* *$ & $* *$ & $* * *$ & $* * *$ & ÖD & ÖD & $*$ \\
Çeșit x Yıl & ÖD & $*$ & ÖD & ÖD & ÖD & $*$ & ÖD & ÖD & ÖD \\
\hline
\end{tabular}

ÖD: Önemli Değil, *: $\mathrm{P}<0.05$ düzeyinde önemli, **: $\mathrm{P}<0.01$ düzeyinde önemli, ${ }^{* * *}: \mathrm{P}<0.001$ düzeyinde önemli

Arslan vd., (2007) 29 farkl1 susam genotipinde 2002-2004 yılları arasında bir çalışma gerçekleştirmişlerdir. Yapmış olduğumuz çalışmadan farklı olarak oleik asit (C18:1) miktarını daha düșük, linoleik asit miktarını (C18:2) ise daha yüksek olarak tespit etmişlerdir. Kurt (2018), 7 farklı coğrafi bölgeden elde ettiği toplam 24 farklı susam çeşidinde yă asitleri kompozisyonunu incelemiştir. Tüm çeşitlerde linoleik asit (C18:2) majör yağ asidi olarak tespit edilmiş olup, ortalama değer \%44,20'dir. Oleik (C18:1), palmitik (C16:0) ve stearik asit (C18:0) miktarlarını ise sirasıly $\% 38.73, \% 8.98$ ve $\% 5.27$ olarak tespit etmiştir.

\section{Sonuçlar}

Dünyanın birçok yerinde yetiştirilen ve ekonomik açıdan önemli yağlı tohumlardan biri olan susam, ihtiva ettiği doymamış yağ asitleriyle de sağlık 
açısından oldukça önemlidir. Özellikle insan vücudunda sentezlenemeyen ve diyetle alınması gereken linoleik asit (C18:2) bakımından oldukça zengindir. Dünya geneline baktığımızda bazı çeşitlerin oleik asit (C18:1) bakımından, bazı çeșitlerin ise linoleik asit (C18:2) bakımından daha zengin olduğu görülmektedir. Yapmış olduğumuz çalışmada incelediğimiz 10 farklı susam genotipinde oleik asit (C18:1) miktarı linoleik asitten (C18:2) daha fazla bulunmuştur. Arslanbey çeşidi, her iki ekim döneminde de en yüksek linoleik asit değerine sahip olduğu için Siirt koşullarında ikinci ürün olarak yetiştirilmesi tavsiye edilebilir. Ayrıca, elde ettiğimiz verilerin yapılacak 1slah çalışmalarında önemli bir kaynak teşkil edeceği düşünülmektedir.

\section{Kaynaklar}

Arslan, Ç., Uzun, B., Ülger, S. and Çağirgan, M.I. (2007). Determination of oil content and fatty acid composition of sesame mutants suited for intensive management conditions. JAOCS, Journal of the American Oil Chemists' Society, 84(10), 917-920. doi: 10.1007/s11746-0071125-6

Arslan, H., Hatipoğlu, H. and Karakuş, M. (2014). Determination of yield and yield components as a second crop of some sesame genotypes collected from Şanlıurfa Region. Turkish Journal of Agricultural Research, 1(2), 109-116.

Ayoubizadeh, N., Laei, G., Amini Dehaghi, M., Masoud Sinaki, J. and Rezvan, S. (2019). Seed yield and fatty acids composition of sesame genotypes as affected by foliar application of iron nanochelate and fulvic acid under drought stress. Applied Ecology and Environmental Research, 16(6), 7585-7604. doi:10.15666/aeer/1606_75857604

Baydar, H. (2005). Susamda Sesamum indicum L. verim, yağ, oleik ve linoleik tipi hatların tarımsal ve teknolojik özellikleri. Akdeniz Üniversitesi Ziraat Fakültesi Dergisi, 18(2), 267-272.

Baydar, H., Turgut, İ. and Turgut, K. (1999). Variation of Certain Characters and Line Selection for Yield, Oil, Oleic and Linoleic Acids in the Turkish Sesame (Sesamum indicum L.) Populations. Turkish Journal of Agriculture and Forestry, 23(4), 431-442.

Baydar, H. ve Turgut, İ. (1999). Yağlı tohumlu bitkilerde yağ asitleri kompozisyonunun bazı morfolojik ve fizyolojik özelliklere ve ekolojik bölgelere göre değişimi. Turkish Journal of Agriculture and Forestry, 23, 81-86.

Chen, Z., Tonnis, B., Morris, B., Wang, R.B., Zhang, A.L., Pinnow, D. and Wang, M.L. (2014).
Variation in seed fatty acid composition and sequence divergence in the FAD2 gene coding region between wild and cultivated sesame. Journal of Agricultural and Food Chemistry, 62(48), 11706-11710. doi:10.1021/jf503648b

Dar, A.A., Kancharla, P.K., Chandra, K., Sodhi, Y.S. and Arumugam, N. (2019). Assessment of variability in lignan and fatty acid content in the germplasm of Sesamum indicum L. Journal of Food Science and Technology, 56(2), 976-986. doi:10.1007/s13197-018-03564-x

Elleuch, M., Besbes, S., Roiseux, O., Blecker, C., and Attia, H. (2007). Quality characteristics of sesame seeds and by-products. Food Chemistry, 103(2), 641-650. doi:10.1016/j.foodchem.2006.09.008

Hama, J.R. (2017). Comparison of fatty acid profile changes between unroasted and roasted brown sesame (Sesamum indicum L.) seeds oil. International Journal of Food Properties, 20(5), 957-967 doi:10.1080/10942912.2016.1190744

Hashempour-Baltork, F., Torbati, M., AzadmardDamirchi, S. and Savage, G.P. (2017). Quality properties of sesame and olive oils incorporated with flaxseed oil. Advanced Pharmaceutical Bulletin, 7(1), 97-101. doi: 10.15171/apb.2017.012

Ji, J., Liu, Y., Shi, L., Wang, N. and Wang, X. (2018). Effect of roasting treatment on the chemical composition of sesame oil. LWT, 101, 191-200. doi:10.1016/j.lwt.2018.11.008

Karaaslan, D. (2007). Evaluation of seed oil, protein content and fatty acid composition in sesame accessions in the Northern Fertile Crescent, Turkey. Asian Journal of Chemistry, 19(6), 4841-4852.

Kurt, C., Arioglu, H., Erdem, T., Akkaya, M.R., El Sabagh, A. and Isalam, M.S. (2016). A comparative study of fatty acid extraction methods of sesame (Sesamum indicum L.) varieties grown under Mediterranean environment. Journal of Experimental Biology and Agricultural Sciences, 4, 588-593. doi:10.18006/2016.4(5s).588.593

Kurt, C. (2018). Variation in oil content and fatty acid composition of sesame accessions from different origins. Grasas Y Aceites, 69(1), 1-9. doi:10.3989/gya.0997171

Mondal, N., Bhat, K.V., and Srivastava, P.S. (2010). Variation in fatty acid composition in Indian germplasm of sesame. Journal of the American Oil Chemists' Society, 87(11), 1263-1269. doi:10.1007/s11746-010-1615-9 
Nzikou, J.M., Matos, L., Bouanga-Kalou, G., Ndangui, C. B., Pambou-Tobi, N.P.G., Kimbonguila, A., Silou, T., Linder, M. and Desobry, S. (2009). Chemical composition on the seeds and oil of Sesame (Sesamum indicum L.) grown in CongoBrazzaville. Advance Journal of Food Science and Technology, 1(1), 6-11.

Özdemir, İ.S., Karaoğlu, Ö., Dağ, Ç. and Bekiroğlu, S. (2018). Assessment of sesame oil fatty acid and sterol composition with FT-NIR spectroscopy and chemometrics. Turkish Journal of Agriculture and Forestry, 42(6), 444-452. doi:10.3906/tar-1802-130

Seçer, A. (2016). Türkiye'de susam üretim ve diş ticaretinde gelişmeler. Çukurova Tarım ve Gıda Bilimleri Dergisi, 31, 27-36.

Spandana, B., Prasad, R.B.N., Sarika, C.H., Anuradha, G., Sivaraj, N. and Sivaramakrishnan, S. (2013). Variation in seed oil content and fatty acid composition in sesame (Sesamum indicum). Indian Journal of Agricultural Sciences, 83(12), 1402-1405.

Şaman, O. \& Öztürk, Ö. (2012). İkinci Ürün Susamda Farklı Bitki Sıklıklarının Verim ve Verim
Unsurları Üzerine Etkileri. Tarım Bilimleri Araştırma Dergisi, 5(1), 118-123.

TS EN ISO 12966-2. (2017). Hayvansal ve bitkisel katı ve sivı yă̆lar- Yă̆ asitleri metil esterlerinin gaz kromotografisi-Bölüm 2: Yă asitleri metil esterlerinin hazırlanması. TSE yayınları, Ankara

Uzun, B., Arslan, Ç. and Furat, Ş. (2008). Variation in fatty acid compositions, oil content and oil yield in a germplasm collection of sesame (Sesamum indicum L.). Journal of the American Oil Chemists' Society, 85(12), 1135-1142. doi:10.1007/s11746-008-1304-0

Ünal, M.K. and Yalçın, H. (2008). Proximate composition of Turkish sesame seeds and characterization of their oils. Grasas Y Aceites, 59(1), 23-26. doi:10.3989/gya.2008.v59.i1.485

Were, B.A., Onkware, A.O., Gudu, S., Welander, M. and Carlsson, A.S. (2006). Seed oil content and fatty acid composition in East African sesame (Sesamum indicum L.) accessions evaluated over 3 years. Field Crops Research, 97(2-3), 254260. doi:10.1016/j.fcr.2005.10.009 